\title{
STUDY OF CRYOPROTECTORAL PROPERTIES OF BIO-POLYSACHARID MIXTURES IN THE COMPOSITION OF MINCED SEMI-PRODUCTS
}

\author{
O. Skochko, V. Druhoveiko, I. Shevchenko, M. Maslikov \\ National University of Food Technologies
}

\begin{tabular}{l}
$\quad$ Key words: \\
Protein-polysaccharide \\
compositions \\
Cryoprotectors \\
Meat systems \\
Broken semifinished \\
products \\
Crystallization centers \\
Deep freezing \\
Water activity \\
\hline
\end{tabular}

Article history:

Received 04.09.2018

Received in revised form

28.09.2018

Accepted 19.10.2018

Corresponding author:

O. Skochko

E-mail:

npnuht@ukr.net

\begin{abstract}
A prerequisite for the preservation of quality of minced semi-finished products after defrosting is compliance with the optimal conditions for refrigeration. However, it is not always possible to maintain high consumer properties of frozen semifinished products, as the degree of destructive influence of low temperatures on muscle fibers of meat raw materials also depends on its quality. In order to stabilize the functional and technological properties of low-grade meat raw material, which is usually included in the composition of semi-finished products and protection from the negative influence of physicochemical factors on the quality of the frozen brooded semifinished products the protein-polysaccharide formulations of cryoprotective action were developed. According to the results of the research, it was established that the use of proteins of blood plasma Vepro 75 PSC, sodium caseinate and plant fiber (wheat, flax, plantain) as part of the chip contribute high quality product with stable consumer properties.

The article presents the results of the influence of proteinpolysaccharide mixtures on the change of functional and technological structural and mechanical properties of model cutlets. It was established that the use of developed cryoprotectors complex mixtures in the model of meat filling systems in the amount of $2 \%$ increases moisture-retaining capacity by 9.7...15.3\%, compared with the control sample, reduces the cryoscopic temperature by $2.09 \ldots 2.81^{\circ} \mathrm{C}$, which positively affects the quality indices of finished products. The most functional composition of the complex cryoprotectors proteinpolysaccharide mixture is established containing the blood plasma protein, sodium caseinate, plantain fiber and flaxseed in equal proportions.

According to the results of the conducted research, the use of protein polysaccharide compositions in the technology of minced semi-finished products allows to maintain a dense structure of semi-finished products after 30 days of storage in a frozen state and promotes the receipt of products of high quality.
\end{abstract}

DOI: $10.24263 / 2225-2924-2018-24-5-25$ 


\title{
ВИВЧЕННЯ КРІОПРОТЕКТОРНИХ ВЛАСТИВОСТЕЙ БІЛКОВО-ПОЛІСАХАРИДНИХ СУМІШЕЙ У СКЛАДІ ПОСІЧЕНИХ НАПІВФАБРИКАТІВ
}

\author{
О.І. Скочко, В.О. Друговейко, І.І. Шевченко, М.М. Масліков \\ Національний університет харчових технологій
}

Необхідною умовою збереження якісних показників посічених напівфабрикатів після розморожування є дотримання оптимальних умов холодильного оброблення. Проте не завжди ие дає змогу зберегти високі споживчі властивості заморожених напівфабрикатів, оскільки ступінь руйнівного впливу низьких мінусових температур на м'язові волокна м'ясної сировини також залежить $і$ від ії якості. 3 метою стабілізації функиіонально-технологічних властивостей низькосортної м'ясної сировини, що входить до складу посічених напівфабрикатів та захисту від негативного впливу фізикохімічних факторів на якість заморожених посічених напівфабрикатів, були розроблені білково-полісахаридні композииї кріопротекторної дії. За результатами проведених досліджень встановлено, що використання білків плазми крові Vерго 75 PSC, казеїнату натрію та рослинної клітковини (пшеничної, льону, подорожника) у складі котлет сприяє отриманню виробів високої якості зі стабільними споживчими властивостями.

У статті наведено результати впливу білково-полісахаридних сумішей на зміну функиіонально-технологічних $і$ структурно-механічних властивостей модельних зразків котлет. Встановлено, щз використання розроблених кріопротекторних комплексних сумішей у складі модельних м'ясних фаршевих систем у кількості 2\% підвищує вологоутримувальну здатнісь на 9,7... 15,3\%, порівняно з контрольним зразком, знижуе кріоскопічну температуру на $2,09 \ldots 2,81^{\circ} \mathrm{C}$, що позитивно впливає на показники якості готових виробів. Визначено найбільш функиіональний склад комплексної кріопротекторної білково-полісахаридної суміші, щяо містить білок плазми крові, казеїнат натрію, клітковину подорожника та льону за рівних співвідношень.

За результатами проведених досліджень встановлено, щя використання білково-полісахаридних композиції у технології посічених напівфабрикатів дає змогу зберегти щільну структуру напівфабрикатів після 30 діб зберігання в замороженому стані і сприяє отриманню продуктів високої якості.

Ключові слова: білково-полісахаридні композииії, кріопротектори, м'ясні системи, посічені напівфабрикати, центри кристалізаиії, глибоке заморожування, активність води.

Постановка проблеми. Незважаючи на підтверджену ефективність, навіть дуже швидке заморожування м'ясної сировини і м'ясних напівфабрикатів без додавання речовин кріопротекторної дії може призвести до незворотних структурно-функціональних змін клітинної й тканинної структур м'ясних системи. Під час зберігання в замороженому стані в м'ясній сировині відбувається денатурація та/або агрегація білків, що спричиняє втрату функціонально-технологічних властивостей білків м'яса. Водночос через пошко- 
дження клітинних мембран порушується баланс окисно-відновних процесів у бік окиснювальних реакцій. Процес розморожування супроводжується втратою вологи, а разом 3 нею й поживних речовин. Запобігання або зниження ступеня денатурації білків під впливом заморожування $\epsilon$ можливим у разі введення до м'ясних систем кріопротекторів. Ефект від використання кріопротекторів у складі м'ясних систем полягає в тому, що їх молекули можуть наближатися або зв'язуватися 3 молекулами білка за будь-якими функціональними групами, утворюючи водневий або іонний зв'язок. Тобто молекули білків ніби вкриваються молекулами кріопротекторів [1]. У наш час актуальною $є$ проблема розробки бінарних білкових композицій, які, крім здатності знижувати негативний вплив низьких температур, можуть нівелювати недоліки низькосортної м'ясної сировини та покращувати текстурні характеристики i харчову цінність м'ясних виробів. Крім того, комбінування тваринних білків у певному співвідношенні сприяє також покращенню їх функціонально-технологічних властивостей за рахунок ефекту синергізму, що проявляється у підвищенні міцності структури змішаних білкових гелів. Проте підбір кріопротекторів для різних м'ясних систем необхідно здійснювати окремо, залежно від їх складу та функціонально-технологічних властивостей $[2 ; 3 ; 4]$.

Мета статті: дослідити кріопротекторні властивості білково-полісіхаридних сумішей тваринних білків і рослинної клітковини для нівелювання негативних наслідків впливу заморожування на функціонально-технологічні властивості м'ясної сировини, запобігання значному кристалоутворенню та уповільнення перебігу процесу заморожування,

Матеріали і методи. Застосовано аналітичні та експериментальні методи досліджень білково-полісахаридних сумішей і м'ясних фаршевих систем: фізико-хімічні (для визначення якісного і кількісного складу та функціональнотехнологічних характеристик), інструментальні (для вимірювання кріоскопічної температури, показник активності води $a_{w}$ ), математичні та математично-статистичні (для математичного моделювання, оптимізації статистичного оброблення експериментальних даних). Пенетрацію посічених напівфабрикатів визначали за глибиною занурення індентора у дослідний зразок за температури $20^{\circ} \mathrm{C}$. Проводили три вимірювання на відкритій поверхні зразка на відстані не менше 10 мм від краю виробу і на максимальній відстані від точок інших вимірювань, щоб деформована частина поверхні не увійшла в зону вимірювання, після чого проводили перерахунок значення пенетрації у значення пенетраційної напруги.

Показник активності води $a_{w}$ модельних фаршевих систем і м'ясних посічених напівфабрикатів визначали за допомогою аналізатора rotronic Hygro Palm-23. Кріоскопічну температуру модельних фаршевих систем і м'ясних посічених напівфабрикатів визначали методом термічного аналізу, що базується на побудові кривих зміни температури у часі.

Як функціонально-технологічні та кріостабілізуючі компоненти у складі м'ясних фаршевих систем було досліджено чотири композиційних сумішей у співвідношенні білкової та полісахаридної складової - 1:1. До їх складу увійшли: білок плазми крові, казеїнат натрію та пшенична клітковина - суміш № 1; білок плазми крові, казеїнат натрію та клітковина льону - суміш № 2; білок плазми крові, казеїнат натрію та клітковину подорожника - 
суміш № 3; білок плазми крові, казеїнат натрію, клітковину подорожника та льону - суміш № 4. Білково-полісахаридні суміші додавали до складу модельних фаршевих систем, виготовлених на основі односортної яловичини $(50 \%)$ та напівжирної свинини $(50 \%)$, у кількості $2 \%$ за рахунок зменшення односортної яловичини. За контроль було обрано м'ясну фаршеву систему без тваринних білків і харчових волокон. Отримані зразки фаршу піддавали перемішуванню за температури $12^{\circ} \mathrm{C}$ протягом $15 \mathrm{xв}$, формували у вигляді котлет і заморожували за температури мінус $18^{\circ} \mathrm{C}$. Тривалість зберігання за зазначеної температури становила 30 діб. У всіх зразках до заморожування, після розморожування й термічного оброблення визначали органолептичні, фізико-хімічні, функціонально-технологічні, структурно-механічні показники, а також показник активності води $a_{w}$ та значення кріоскопічної температури.

Результати та їх обговорення. Обрані як кріостабілізатори білки плазми крові Vepro 75 PSC та казеїнату натрію є термостабільними функціональними білками, що використовується як при мінусових температурах, так і в режимах пастеризації. Вони $є$ високомолекулярними речовинами, що здатні знижувати швидкість зростання кристалів та захищати клітини м'язової тканини від осмотичних перепадів. Крім того, вони володіють високими функціональними властивостями та здатністю стабілізувати м'ясні системи.

Харчові волокна пшеничної клітковини, клітковини льону та клітковини подорожника $є$ поліфункціональними компонентами, що здатні покращити консистенцію, адсорбувати воду, зменшити втрати маси та збагатити кінцевий продукт баластними речовинами, але як і більшість волокон, що містять суміш розчинних і нерозчинних фракцій, мають невисоку здатність адсорбувати жир [1-3].

Таблиия 1. Органолептична оцінка термооброблених модельних зразків котлет $(n=3, P \geq 0,95)$

\begin{tabular}{|c|c|c|c|c|c|}
\hline \multirow{2}{*}{ Назва показника } & \multicolumn{5}{|c|}{ Дослідні зразки } \\
\hline & контроль & зразок 1 & зразок 2 & зразок 3 & зразок 4 \\
\hline $\begin{array}{l}\text { Зовнішній } \\
\text { вигляд }\end{array}$ & \multicolumn{5}{|c|}{$\begin{array}{c}\text { форма овальна, поверхня рівномірно покрита паніровкою, } \\
\text { без розірваних ломаних країв }\end{array}$} \\
\hline Вигляд на розрізі & $\begin{array}{l}\text { спостерігається відо- } \\
\text { кремлення вологи }\end{array}$ & \multicolumn{4}{|c|}{ фарш добре перемішаний } \\
\hline Смак ізапах & \multicolumn{5}{|c|}{$\begin{array}{c}\text { сирих — властиві доброякісному м'ясу; у смаженому вигляді — властиві } \\
\text { продукту без сторонніх присмаків та запаху, з ароматом прянощів }\end{array}$} \\
\hline Консистенція & $\begin{array}{c}\text { сирих - рихла, крихка } \\
\text { в смаженому вигляді }\end{array}$ & \multicolumn{4}{|c|}{$\begin{array}{l}\text { сирих — щільна, готових соковита, ніжна, } \\
\text { некрихка, рівномірно перемішаний фарш }\end{array}$} \\
\hline $\begin{array}{c}\text { Температура в } \\
\text { товщі замороже- } \\
\text { ного продукту, }{ }^{\circ} \mathrm{C}\end{array}$ & \multicolumn{5}{|c|}{ Не вище мінус 10} \\
\hline Маса виробу, г & \multicolumn{5}{|c|}{$70 \pm 5$} \\
\hline
\end{tabular}

При органолептичному дослідженні модельних зразків котлет встановлено, що використання розроблених білково-полісахаридних сумішей у кількості 2\% не призводить до помітних змін органолептичних властивостей дослідних зразків котлет, натомість сприяє покращенню їх консистенції та підвищенню соковитості. Усі зразки до заморожування володіли рожево-червоним забарвленням, запахом, властивим свіжому м'ясу та ніжною консис- 
тенцією. Дослідні зразки характеризувалися більшою липкістю порівняно 3 контрольним зразком. Після розморожування дослідні зразки мали більш темне забарвлення. Найбільші зміни органолептичних показників після заморожування, зберігання протягом 30 діб і розморожування були властиві контрольним зразкам, що характеризувалися розрихленою структурою м'язової тканини та кислуватим запахом (табл. 1).

3 метою розроблення рекомендацій щодо застосування досліджуваних білково-полісахаридних сумішей як функціонально-технологічних інгредієнтів 3 кріостабілізуючими властивостями у виробництві посічених напівфабрикатів було досліджено хімічний склад і функціонально-технологічні властивості модельних м'ясних фаршевих систем з їх використанням. Результати досліджень представлені в табл. 2. Проведені дослідження дають змогу стверджувати, що введення як кріопротекторів у м'ясні фаршеві системи білковополісахаридних композицій позитивно впливає на збільшення вологоутримувальної здатності на 9,7-17,3\% та жироутримувальної здатності на $9,4 \ldots 9,7 \%$ модельних м'ясних систем, порівняно з контрольним зразком, що безумовно сприяє покращенню структури модельних зразків котлет (табл. 2).

Таблиия 2. Хімічний склад, функціонально-технологічні та структурно-механічні характеристики модельних зразків котлет $(n=3 ; P \geq 95)$

\begin{tabular}{|c|c|c|c|c|c|}
\hline Показники & Контроль & Зразок № 1 & Зразок № 2 & Зразок № 3 & Зразок № 4 \\
\hline $\begin{array}{c}\text { Масова частка } \\
\text { вологи, \% }\end{array}$ & 69,95 & 71,47 & 71,50 & 72,67 & 72,56 \\
\hline $\begin{array}{c}\text { Масова частка } \\
\text { білка, \% }\end{array}$ & 9,89 & 10,61 & 10,63 & 10,60 & 10,65 \\
\hline $\begin{array}{c}\text { Масова частка } \\
\text { жиру, \% }\end{array}$ & 19,46 & 17,19 & 17,14 & 16,00 & 16,06 \\
\hline $\begin{array}{c}\text { Масова частка } \\
\text { золи, \% }\end{array}$ & 0,70 & 0,73 & 0,73 & 0,73 & 0,73 \\
\hline рН, & 6,0 & 6,02 & 6,07 & 6,08 & 6,07 \\
\hline В33, \% & 78,20 & 79,09 & 79,85 & 80,10 & 81,14 \\
\hline ВУ3, \% & 67,90 & 74,50 & 74,70 & 75,1 & 75,79 \\
\hline ЖУ3, \% & 68,00 & 74,40 & 74,52 & 74,63 & 74,57 \\
\hline $\begin{array}{c}\text { Емульгуюча } \\
\text { здатність, \% }\end{array}$ & 69,80 & 79,90 & 79,86 & 79,91 & 79,88 \\
\hline $\begin{array}{c}\text { Стабільність } \\
\text { емульсії, \% }\end{array}$ & 77,30 & 89,40 & 90,40 & 89,95 & 90,02 \\
\hline Вихід & 74,58 & 80,76 & 81,30 & 81,78 & 81,83 \\
\hline Пенетрація, мм & 28,4 & 19,7 & 17,9 & 17,6 & 17,09 \\
\hline $\begin{array}{c}\text { Пенетраційна } \\
\text { напруга, Па }\end{array}$ & 17,25 & 24,87 & 27,37 & 27,54 & 27,63 \\
\hline
\end{tabular}

Результати досліджень свідчать також про зростання стабільності м'ясних систем дослідних зразків на $15,7-16,5 \%$ порівняно 3 контрольним зразком. Отже, представлені результати дослідження зазначених показників дають повну уяву про м'ясні системи, їх структуру, здатність поглинати та утримувати вологу під час теплової обробки [2-8].

Зниження показника активності води $a_{w}$ у дослідних зразках обумовлює відповідне зниження температури початку кристалізації вологи у м'ясних 
фаршевих системах і, відповідно, зміну характеру процесу кристалізації води у клітинній структурі м'язової тканини $[5 ; 8]$. Так, значення кріоскопічної температури становило для контрольного зразка мінус $1,75^{\circ} \mathrm{C}$. Кріоскопічна температура дослідних зразків суттєво знижувалася і становила для зразків: № 1 - мінус $3,84^{\circ} \mathrm{C}$; № 2 - мінус $4,16^{\circ} \mathrm{C}$; № 3 - мінус $4,58^{\circ} \mathrm{C}$; № 4 - мінус $4,56^{\circ} \mathrm{C}$. Збільшення показника $a_{w}$ порівняно зі значеннями до заморожування для дослідних зразків на 0,002 , а для контрольного - на 0,005 , пояснюється частковим руйнуванням клітинних стінок і виділенням м'ясного соку та $\epsilon$ більш суттєвим для контрольного зразка $[3 ; 5 ; 6]$.

При заморожуванні і зберіганні в замороженому стані протягом 30 діб змінюється також концентрація водних розчинів м'ясних систем, що впливає на зміну показника $\mathrm{pH}$ та сили іонних взаємодій у наближеному до молекули білка шарі. Це явище $є$ наслідком не лише дегідратації та агрегації, але й розпаду глікогену, що залишився у м'ясі до заморожування, та утворення молочної кислоти. Під час заморожування, зберігання, розморожування й термічного оброблення у посічених напівфабрикатах спостерігалось незначне зниження величини $\mathrm{pH}$ на $0,02-0,04$ відносно початкового рівня $\mathrm{pH}$.

\section{Висновки}

Отримані результати підтверджують доцільність використання білковополісахаридних сумішей у кількості $2 \%$ як речовин, дії яких направлені на кріозахист м'ясних фаршевих систем від впливу низьких температур. Їх стабілізуюча дія проявляється у зниженні негативного впливу фізико-хімічних факторів на якісні показники посічених напівфабрикатів, у покращенні їх консистенції та підвищенні соковитості. Доведено, що найбільш функціональною є білково-полісахаридна суміш, що містить білок плазми крові, казеїнат натрію, клітковину подорожника та льону в рівних співвідношеннях (суміш 4).

\section{Лiтература}

1. Рогов И.А. Химия пищи. Кн. 1 (Белки: структура, функции, роль в питании). Москва: КолосС, 2007. 853 c.

2. Салаватулина Р.М. Рациональное использование сырья в колбасном производстве. Санкт-Петербург: ЗАО Торговый дом Георд, 2005. 236 с.

3. Фейнер Г. Мясные продукты. Научные основы, технологии, практические рекомендации / пер. с англ. Н.В. Магды. Санкт-Петербург: Профессия, 2010. 720 с.

4. Differences in the structure and dynamics of the adsorbed layers in protein stabilized model foams and emulsion / D.C. Clark, R.M. Alan, J. Pete et al.; Royal Society of Chemistry. Faraday Discussion. 1994. Vol. 98. P. 253-262.

5. Куцакова В.Е., Бараненко А.В., Бурова Т.Е., Кременевская М.И. Холодильная технология пищевых продуктов. Часть III. Биохимические и физико-химические основы. Санкт-Петербург: ГИОРД, 2011. 272 с.

6. Сязин И.Е., Касьянов Г.И. Феномен криообработки продуктов: монография. Саарбрюккен, Германия: Palmarium Academic Publishing, 2012. 296 с.

7. Касьянов Г.И., Квасенков О.И., Сязин И.Е., Кочерга А.В. Инновационные технологии криообработки сельскохозяйственного сырья: монография. Краснодар: Изд. ФГБОУ ВПО «КубГТУ», 2013. 147 с.

8. Shevchenko I., Skochko A. Advantages of using proteins in the production of truncated semi-finished products. Food and Environment Safety. Journal of Faculty of Food Engineering, Ştefan cel Mare University. Suceava Volume XVII, Issue 3. 2018. P. 272-277. 